\title{
Optical standards: the missing link in optics and photonics educational programs
}

\section{Nikolay Stoev}

Nikolay Stoev, "Optical standards: the missing link in optics and photonics educational programs," Proc. SPIE 9664, Ninth International Topical Meeting on Education and Training in Optics and Photonics, 96641C (24 October 2005); doi: 10.1117/12.2207778

SPIE Event: Ninth International Topical Meeting on Education and Training in Optics and Photonics, 2005, Marseille, France 
This paper is freely available as a resource for the optics and photonics education community.

\title{
Ref ETOP093
}

\section{Optical standards: the missing link in optics and photonics educational programs}

\author{
Nikolay Stoev
}

\begin{abstract}
s
Educational programs in optics and photonics contain superior fundamental and specialized courses, and yet optical standards and standardization aspects are often missing from the curricula. Although international standardization aims at eliminating technical barriers to trade, many graduates learn about industry standards during their first job. This presentation provides an overview of existing standards in optics and photonics and latest developments in the field. It provides information about the international organizations involved and the specialty areas covered by standards. Courses or educational modules covering existing industry standards and international standardization efforts may become a valuable addition to educational programs in optics and photonics.
\end{abstract}

\section{Introduction}

\section{Summary}

Many of today's educational programs in optics and photonics contain first-class fundamental and/or specialized courses, and yet optical standards and standardization aspects of optical engineering often remain missing from the curricula. Although the purpose of international standardization is to eliminate technical barriers to trade, many graduates only learn about industry standards during their first or second "real world" job. This presentation provides an overview of the existing standards in optics and photonics and the latest developments in the field. It provides information about the international organizations involved in this effort and the various specialty areas in optics and photonics covered by standards. Courses or educational modules covering exisiting industry standards and international standardization efforts may become a valuable addition to educational programs in optics and photonics.

\section{The role of industry standards}

The main goal of international standardization is to eliminate technical barriers to trade. There are hundreds of international standards for terminology, requirements, interfaces, test methods and product safety, that apply to complete systems, devices, instruments, optical and photonic components, auxiliary devices and accessories, and materials. In addition to traditional fields like lighting, photography, cinematography, telescopes, microscopes, geodetic and surveying equipment, ophthalmic and medical optics, there are newer fields such as fiber optics and free space telecommunication systems, lasers and other electrooptical devices and systems. A brief survey of university and college curricula in North America has revealed that standards and standardization aspects have very limited coverage. Except for black body emitters, optical frequency standards and interferometer calibration, there was practically no other content on industry standards. Yet knowledge of relevant industry standards is essential for optical engineers, supporting their efforts in commercializing new technologies or developing new products. Failing just one specification of a product performance standard may lead to significant delays in bringing the product to the market, additional costs, losses and may even result in the collapse of a start-up venture. Some products are subject to legal regulations, e.g. medical, lasers, or electronic products incorporating lasers or LEDs. In such cases, standards help manufacturers to show compliance with the relevant regulations and represent an important mechanism for accessing the market or gaining competitive advantage. Failure to meet existing product safety standards may result in legal action against the product manufacturer. 


\section{Standardization organizations and specialty areas}

The standardization efforts are coordinated by international organizations such as ISO, IEC, CEN, CENELEC, CIE and all the work is done by members of technical committees (TC) specializing within particular technical areas. Participating countries are represented by members of the national standards organizations or members of the national subcommittees for the respective TC, SC or working group (WG). The specialty areas include traditional technologies such as cinematography, photography, geodetic and surveying optical instruments as well as new technologies such as fiber optics and lasers. Table 1 presents an overview of the various specialty areas, technical committees, and selected market indicators where available.

Table 1. Standards in Optics and Photonics and related technical fields

\begin{tabular}{|l|l|l|l|}
\hline Committee & Scope or specialty area & $\begin{array}{l}\text { Market } \\
\text { inidicator } \\
\text { (Billion US) }\end{array}$ & Comment \\
\hline ISO/TC 36 & Cinematography & 20.3 & Note 1 \\
\hline ISO/TC 42 & Photography & 11.87 & Note 2 \\
\hline ISO/TC 171 & $\begin{array}{l}\text { Document management (micrographic } \\
\text { and electronic) }\end{array}$ & 1.03 & 2003 \\
\hline ISO/TC 172 & Optics and photonics & 75 & Note 3 \\
\hline ISO/TC 172/SC1 & Fundamental standards & & Note 3 \\
\hline ISO/TC 172/SC3 & Optical materials and components & 5.8 & Note 3 \\
\hline ISO/TC 172/SC4 & Telescopic systems & 6.0 & Note 3 \\
\hline ISO/TC 172/SC5 & Microscopes and endoscopes & 2.2 & Note 3 \\
\hline ISO/TC 172/SC6 & Geodetic and surveying instruments & 4.6 & \\
\hline ISO/TC 172/SC7 & Ophthalmic optics and instruments & 31.9 & \\
\hline ISO/TC 172/SC9 & Electro-optical systems & 24.5 & \\
\hline CEN/TC 123 & Lasers and laser-related equipment & & \\
\hline CEN/TC 170 & Ophthalmic optics laser & & \\
\hline IEC/TC 76 & $\begin{array}{l}\text { Optical radiation safety and } \\
\text { equipment }\end{array}$ & \\
\hline IEC/TC 86 & Fiber optics for telecommunications & & \\
\hline IEC/TC 100 & $\begin{array}{l}\text { Audio, video and multimedia systems } \\
\text { and equipment }\end{array}$ & & \\
\hline CIE Division 2 & $\begin{array}{l}\text { Physical measurement of light and } \\
\text { Optical Radiation }\end{array}$ & & \\
\hline CIE Division 6 & Photobiology and Photochemistry & & \\
\hline CIE Division 8 & Image Technology & \\
\hline $\begin{array}{l}\text { Note 1: Worldwide box office receipts for 2003 } \\
\text { Note 2: Imports of digital cameras and printers in 2000 to USA } \\
\text { Note 3: Market share estimates are from the COSE Report "Harnessing Light" }\end{array}$ \\
\hline
\end{tabular}

The presentation contains further details about the standards and publications within selected technical fields (lasers, electro-optics and laser product safety) as well as information about recent changes and developments. Including topics on standards and standardization in educational programs in optics and photonics would help complement the existing curricula with valuable industry-driven content. 